Jurnal Konstruksi Hukum | ISSN: XXXX | E-ISSN: XXXX

Vol. 1, No. 2, Oktober 2020, Hal. 329-333| Available online at https://www.ejournal.warmadewa.ac.id/index.php/jukonhum

DOI: https://doi.org/10.22225/jkh.1.2.2555.329-333

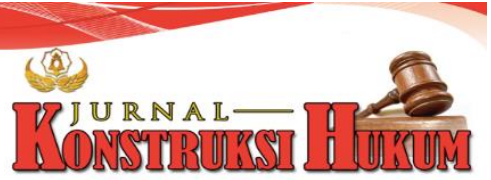

\title{
TANGGUNG JAWAB NOTARIS TERHADAP AKTA OTENTIK YANG DIBUATNYA TERKAIT JANGKA WAKTU PENSIUN
}

\author{
I Gusti Ayu Ria Rahmawati, I Nyoman Putu Budiartha, Ni Gusti Ketut Sri Astiti \\ Fakultas Hukum Universitas Warmadewa, Denpasar-Bali, Indonesia
}

\begin{abstract}
Abstrak
Akta otentik merupakan suatu surat yang bentuknya telah ditentukan oleh Undang-undang yang bisa dijadikan sebagai alat bukti yang sempurna yang dibuat dihadapan notaris. Notaris yang bersangkutan harus bertanggung jawab penuh apabila terjadi permasalahan terkait dengan akta yang dibuatnya tersebut baik secara Perdata, Pidana, UUJN dan Kode Etik. Notaris akan terlepas dari seluruh tanggung jawab tersebut apabila telah pensiun dari jabatannya. Penelitian ini bertujuan untuk mengetahui tanggungjawab notaris terhadap akta otentik yang dibatalkan di pengadilan dan yang dibuatnya setelah masa pension. Metode penelitian yang digunakan yaitu hukum normative dengan menggunakan pendekatan perundang-undang dan pendekatan konseptual. Hasil analisis menunjukan bahwa tanggung jawab Notaris terhadap akta otentik yang dibuatnya ketika dinyatakan batal di pengadilan dapat dibagi 4 yakni a) anggung jawab secara perdata, b) tanggung jawab secara Pidana, c) tanggung jawab didasarkan UUJN, d) Tanggung jawab berdasarkan Kode Etik. Kemudian, notaris masih bertanggungjawab kendatipun waktu jabatan Notaris itu sudah selesai atau telah pensiun. Ini bisa dijalankan para pihak berwenang selama akta otentik batal demi hukum itu tengah ada pada tenggang waktu 30 tahun terhitung sejak tanggal akta tersebut dibuat oleh Notaris. Melalui penelitian ini, diharapkan ketentuan mengenai tanggung jawab Notaris setelah pensiun lebih dipertegas terkait batas maksimalnya agar tidak menimbulkan permasalahan baik kepada Notaris maupun kepada pihak yang bersangkutan.
\end{abstract}

Kata Kunci: Tanggung Jawab; Notaris; Akta Otentik; Pensionary

\begin{abstract}
An authentic deed is a letter whose form has been determined by law that can be used as perfect evidence made before a notary public. The notary concerned must take full responsibility in case of problems related to the deed he made, whether in Civil, Criminal, UUJN and Code of Ethics. The notary will be released from all of these responsibilities if he has retired from his position. This study aims to determine the responsibility of the notary for authentic deeds that are canceled in court and made after the retirement period. The research method used is normative law using a statutory approach and a conceptual approach. The results of the analysis show that the notary's responsibility for the authentic deed he makes when declared canceled in court can be divided into 4, namely a) civil liability, b) criminal responsibility, c) responsibility based on UUJN, $d$ ) Responsibility based on the Code of Ethics. Then, the notary is still responsible even though the notary's term of office has ended or has retired. This can be carried out by the authorities as long as the authentic deed is null and void in existence at a grace period of 30 years from the date the deed is drawn up by the Notary. Through this research, it is hoped that the provisions regarding the responsibility of the notary public after retirement will be more defined regarding the maximum limit so as not to cause problems for both the notary and the party concerned.
\end{abstract}

Keywords: Responsibility; Notary; Authentic Deed; Pension

\section{PENDAHULUAN}

Hukum mempunyai peranan penting dalam mengatur kehidupan masyarakat. Bagi masyarakat hukum digunakan sebagai perlindugan yang dapat memberikan keamanan serta ketertiban bermasyarakat. Dalam kasus ini, sektor pelayanan jasa Notaris bisa dikatakan sangat penting, terlebih sebagai pejabat yang diberi tugas oleh Negara untuk melayani masyarakat dibidang keperdataan khsususnya pembuatan 
akta otentik. Secara umum, akta merupakan sebuah surat yang diberi tanda tangan, dimana surat itu berisi keterangan terkait suatu kejadian atau beberapa hal dasar dari suatu hak atau suatu perjanjian (Tresna, 1993). Melalui akta yang dikerjakanya, Notaris dituntut untuk bisa meyebarkan kejelasan hukum terhadap warga pemakai layanan Notaris (Prajitno, 2010). Akta disebut juga akta otentik dimana akta ini punya kekuatan hukum yang dapat dijaminan kepastian hukumnya yang merupakan alatbukti tulis yang sempurna (volledig bewijs), tanpa memerlukan alat bukti lain. Akta yang disusun oleh (door) Notaris saat praktik Notaris merupakan akta relas yaitu berisi berita acara yang dipandang dan dibuat dihadapan Notaris sendiri berdasarkan kedua belah pihak dimana untuk selanjutnya agar segala tingkah atau kegiatan mereka yang akan dilaksanakan, dibuat berwujud akta Notaris (Adjie, 2008).

Beberapa penelitian mengenai tanggung jawab seorang notaris dalam pembuatan surat akta telah banyak dilakukan sebelumnya seperti Hendra (2012); Muhammad, Widowaty, \& Raharjo (2019); Santyaningtyas \& Zubaidi (2020); Tedjosaputro (2020); Utami, Ali, \& Din (2016). Mengenai tanggung jawab apabila dikaitkan dengan masa jabatan Notaris, maka Notaris yang telah pensiun dari jabatannya secara langsung notaris itu dapat terlepas dari hak dan kewajibannya sebagai notaris. Arti pensiun yang dimaksud, dalam hal ini, ialah Notaris yang telah terhenti dari jabatannya. Pasal 65 UUJN menentukan sebagai berikut "Notaris, Notaris Pengganti, dan Pejabat Sementara Notaris bertanggung jawab atas setiap Akta yang dibuatnya meskipun Protokol Notaris telah diserahkan atau dipindahkan kepada pihak penyimpan Protokol Notaris". Dalam pasal tersebut disebutkan bahwa Notaris bertanggung jawab terhadap setiap akta yang dibuatnya meskipun Protokol Notaris telah diserahkan kepada pihak penyimpan Protokol Notaris. Jadi tidak ada penjelasan yang terperinci terkait dengan limitasi tanggung jawab notaris pasca pensiun terhadap akta otentik yang dibuatnya. Dengan kata lain seorang Notaris tetap bertanggung jawab terhadap akta yang dibuatnya meskipun masa jabatan Notaris tersebut telah berakhir.

Ketentuan dalam Pasal 65 UUJN tersebut adalah merupakan norma kabur, mengingat peraturan ini tidak mengatur secara jelas bentuk tanggung jawab jika akta otentik yang dibuat Notaris itu dinyatakan batal di pengadilan saat notaris itu telah pensiun. Sesuai dengan penjelasan tersebut, timbulah pertanyaan mengenai bagaimanakah tanggung jawab seorang Notaris untuk akta otentik yang telah mereka buat bila dibatalkan di pengadilan dan sampai kapan notaris tersebut bertanggung jawab terhadap akta tersebut setelah pensiun dari jabatannya. Berdasarkan uraian tersebut diatas maka penelitian ini bertujuan untuk mengetahui tanggung jawab Notaris terhadap akta otentik yang dibatalkan di pengadilan dan mengetahui kapan tanggung jawab Notaris terhadap akta otentik yang dibuatnya setelah masa pensiun.

\section{METODE PENELITIAN}

Penelitian ini menggunakan model penelitian hukum normative. Dalam metode penelitian hukum normatif yang dikaji ialah hukum tertulis atas semua aspek, kecuali aspek terapan atau implementasinya. Adanya kekaburan norma dalam hal ini dikaitkan dengan kurang jelasnya pengaturan akan penjelasan sampai kapan Notaris harus mempertanggung jawabkan akta otentik yang diciptakannya apabila saat sudah pensiun dari jabatannya. Pendekatan permasalahan yang digunakan adalah pendekatan perundang-undang (statute approach) dan pendekatan konseptual (conceptual approach) (Amiruddin \& Asikin, 2012). Sumber data yang digunakan dalam penelitian ini adalah dokumen berupa Kitab Undang-Undang Hukum Perdata, Kitab Undang-Undang Hukum Pidana, Undang-Undang Nomor 30 Tahun 2004 tentang Jabatan Notaris, Undang-Undang Republik Indonesia Nomor 2 Tahun 2014 tentang Perubahan atas Undang-Undang Nomor 30 Tahun 2004 tentang Jabatan Notaris, Kode Etik Notaris dan peraturan perundang-undangan yang terkait yang lain.

Teknik yang digunakan dalam proses mengumpulkan bahan hukum untuk penelitian ini yaitu, dengan teknik telaah kepustakaan (study document). Dimana dalam teknik ini peneliti menggunakan sistem dengan kartu (card system) atau memahami lewat catatan isi materi dari sub-sub bahan yang didapat dari bahan hukum primier, bahan hukum sekunder dan juga bahan hukum tersier.

\section{HASIL DAN PEMBAHASAN}

\section{Tanggung Jawab Notaris terhadap Akta Otentik yang Dibatalkan di Pengadilan}

Lahirnya tanggung jawab seorang notaris tidak terlepas dari kewajiban dan kewenangan untuk yang diemban. Seorang Notaris dibebankan tanggung jawab atas kebenaran formil, materiil akan akta yang ia buat jikalau Notaris memang terbukti dalam pengadilan bahwa Notaris melakukan kecerobohan atau 
yang disengaja hingga merugikan para pihak (Notodisoerjo, 2010). Dengan kata lain, akta otentik yang disahkan dimuka Notaris dapat dikatakan batal dalam putusan pengadilan hingga para pemegang akta akan merasa telah dirugikan atas akta tersebut maka Notaris tersebut perlu bertanggung jawab terhadap kesalahannya. Dalam hal pertanggungjawaban terhadap akta yang dibuatnya selama menjabat, Notaris tetap bertanggung jawab terhadap semua akta itu sampai Notaris tersebut pensiun. Pertangungjawaban akta tersebut dibedakan menjadi empat, yaitu:

1. Tanggung Jawab Notaris Secara Perdata

Semua peraturan yang diatur pada UUJN hanya memberikan sanksi terhadap pelanggran Notaris sifatnya formil, misal aturan penerbitan akta serta lainnya. Tetapi, Notaris pula mempunyai pertanggung jawaban dalam bahan pada akta yang diterbitkannya. Pada wewenang Notaris pada pemberian nasihat hukum untuk para penghadap (Pasal 15 huruf e UUJN). Andaikata Notaris keliru dalam pemberiam penyuluhan hukum terhadap para penghadap mempunyai hubungan dengan akta yang diterbitkannya, Notaris mempunyai pertanggungjawaban dari perspektif perdata dalam kebenaran materiil dalam akta yang diterbitkannya.

2. Tanggung Jawab Notaris secara Pidana

Perbuatan pidana ialah tindakan yang tidak diperbolehkan oleh suatu peraturan hukum, larangan itu diikuti dengan pengancama yakni sanksi yang mempunyai bentuk pidana tertentu bagi siapapun yang melakukan pelanggaran itu. Perbuatan pidana dikatakan selaku tindakan yang tidak diperbolehkan aturan hukum, dan jika terdapat pelanggaran terkait larangan itu maka akan disertai dengan sanksi, berbentuk pidana tertentu. Pada melaksanakan jabatan selaku Notaris, pidana yang dimaksud ialah pidana yang dijalankan Notaris selaku pejabat umum yang mempunyai wewenang menerbitkan akta otentik yang diatur pada UUJN.

3. Tanggung Jawab Notaris berdasarkan UUJN

Pasal 65 UUJN menyebutkan bahwa Notaris mempunyai pertanggung jawaban pada akta yang diterbitkannya biarpun protokol Notaris sudah menyerahkan ke penerima protokol. Pada pasal tersebut menjabarkan, Notaris menyandang suatu pertanggung jawaban kepada aktanya berlandaskan UUJN.

4. Tanggung Jawab Notaris berdasarkan Kode Etik

Selaku pejabat umum Notaris didalam menjalankan tugasnya tidak boleh lepas dari etika. Etika yang dimaksud disini ialah kode etik profesi Notaris yang ada dan bertujuan agar notaris benarbenar menjalankan tugasnya dengan profesional, bermoral serta terampil dalam argumentasi rasional (Tobing, 1996).

Notaris harus tetap berpatokan pada peraturan-peraturan yang ada serta pada kode etik profesi saat menjalankan tugas dan wewenangnya. Terkait dengan ini tujuan dalam penjagaan harkat serta martabat seorang notaris karena jabatan yang diduduki notaris merupakan jabatan kepercayaan langsung yang diutus oleh Negara. Berkaitan dengan hal itu Notaris juga diharapkan untuk dapat patuh pada setiap peraturan yang ada dalam masyarakat, tidak hanya patuh pada peraturan yang mengatur mengenai jabatannya. Hal ini tentu bertujuan supaya masyarakat serta semua pihak bisa mengerti bahwa profesi Notaris merupakan profesi yang sangat mulia serta berartabat.

\section{Tanggung Jawab Notaris terhadap Akta Otentik yang Dibuatnya Setelah Masa Pensiun}

Dalam kehidupan bermasyarakat Notaris sangat dipercaya sebagai seorang yang ahli di bidang perdata khususnya di bidang kenotariatan, maka dalam menjalankan profesinya notaris harus bertanggungjawab terhadap setiap akta yang dibuatnya, selain itu Notaris dalam menjalankan jabatannya harus berdasarkan karakter khusus, yaitu: 1. Jujur akan dirinya sendiri; 2. Baik dan benar; 3.Profesional (Prajitno, 2010). Walaupun demikian notaris dalam mengemban jabatannya tetap memiliki batasan dalam segi wewenang, begitu pula dengan tanggung jawabnya. Batas waktu tanggung jawab notaris pada akta otentik diterbitkannya secara umum dibatasi oleh kemampuan fisik dan keohanian dari Notaris itu sendiri. Notaris yang telah berhenti menjabat maka terhenti pula segala kewenangan dalam membuat akta serta kewenangan-kewenangan lain yang pernah dimilikinya selama menjabat.

Terkait dengan hal tersebut terdapat kekaburan norma dalam peraturan jabatan notaris yaitu dalam ketentuan pasal 65 UUJN megenai pertanggungjawaban seorang notaris terhadap akta yang dibuatnya setelah notaris itu pensiun. Dalam pasal tersebut tidak terdapat kepastian hukum terlihat dari tidak 
jelasnya aturan yang menyebutkan mengenai batas waktu tanggung jawab notaris setelah pensiun kepada akta yang pernah diterbitkannya selama menjabat.

Secara umum setiap jabatan yang ada pasti memiliki batas waktu, baik terhadap wewenangnya maupun tanggung jawabnya yaitu sepanjang yang bersangkutan masih mengemban jabatan, dan saat jabatan yang diemban telah berakhir maka segala tanggung jawab dan wewenangnya juga akan ikut berakhir. Dalam profesi notaris batas waktu notaris itu bertanggungjawab terhadap akta yang dibuatnya adalah sepanjang notaris itu menjabat hingga notaris itu pensiun pada usia 65 (enam puluh lima) tahun atau dapat diperpanjang sampai notaris itu berumur 67 (enam puluh tujuh) tahun, atau notaris itu telah mengundurkan diri dari jabatannya.

Jika dilihat dari jabatannya maka notaris hanya berwenang dan bertanggungjawab terhadap akta yang pernah dibuatnya hanya pada saat notaris yang bersangkutan masih menjabat sebagai seorang notaris dan saat itu juga semua tanggung jawab dan wewenang itu akan lepas dari notaris itu sendiri ketika Notaris telah melepaskan jabatannya atau pensiun. Akta otentik yang diterbitkan dihadapan Notaris akan tetap berlaku serta bersifat memaut bagi para pihak walaupun notaris yang bersangkutan telah pensiun dari jabatannya. Akta otentik yang diterbitkan dimuka notaris akan tetap sah selaku bukti sempurna, dan apabila dikemudian hari akta tersebut dibatalkan di pengadilan pada saat notaris tersebut telah pensiun sering timbul asumsi dalam kalangan masyarakat bahwa notaris itu lepas dari tanggung jawab karena notaris itu telah pensiun. Batas waktu Pertanggung jawaban notaris dapat dilihat dari daluwarsa akta tersebut. Daluwarsa dapat dilihat dari dua sisi yaitu masa berlaku di dasarkan hukum perdata yakni 30 tahun sedangkan masa berlaku didasarkan hukum pidana yakni 12 tahun. Secara khusus UUJN tidak mengatur mengenai masa berlaku karena setelah masa pensiun semua akta akan di simpan serta diteruskan oleh Notaris penerima akta tersebut, dan bisa dibuka lagi abila suatu saat nanti diperlukan oleh para pihak yang berkepentingan.

Notaris tetap dapat diminta untuk bertanggungjawab atas akta yang dibuatnya selama menjabat bila suatu saat nanti akta tersebut dibatalkan di pengadilan meskipun notaris telah pensiun dari jabatannya, hal ini dapat dilakukan oleh para pihak yang merasa dirugikan atas akta tersebut dan berlaku sepanjang masih dalam tenggang waktu 30 (Tiga Puluh) tahun dihitung dari tanggal akta tersebut dibuat oleh Notaris untuk menciptakan adanya suatu kepastian hukum, sehingga hal ini sesuai dengan maksud dari teori tanggung jawab.

\section{SIMPULAN DAN SARAN Simpulan}

Adapun kesimpulan dari pembahasan tersebut diatas yaitu tanggung jawab Notaris terhadap akta otentik yang dibuatnya ketika dinyatakan batal di pengadilan dapat dibagi 4 yakni a) Tanggung jawab secara perdata; b) Tanggung jawab secara Pidan; c) Tanggung jawab didasarkan UUJN; d) Tanggung jawab berdasarkan Kode Etik. Kemudian, akta otentik yang diterbitkan dimuka Notaris jika dinyatakan batal di pengadilan serta merugikan para pihak, Notaris bisa dimintai tanggung jawab kendatipun waktu jabatan Notaris itu sudah selesai atau dalam kata lain Notaris itu telah pensiun. Ini bisa dijalankan para pihak selama akta otentik batal demi hukum itu tengah ada yakni pada tenggang waktu 30 tahun terhitung sejak tanggal akta tersebut dibuat oleh Notaris.

\section{Saran}

Dalam menjalankan tugas dan wewenang, pejabat Notaris harus tetap berpedoman pada ketentuan UUJN dan kode etik Notaris agar terhindar dari permasalahan yang mungkin timbul nanti dan dapat merugikan notaris itu sendiri, namun apabila dikemudian hari akta yang Notaris buat terbukti bermasalah dan dinyatakan batal di pengadilan maka Notaris harus bertanggungjawab sesuai dengan tanggungjawab yang dibebankan. Dalam pembuatan Undang-undang badan pemerintahan harusnya dapat lebih mempertegas ketentuan yang mengatur tentang janka waktu Notaris menyandang tanggung jawab pada akta otentik yang diterbitkannya seusai pensiun, sehingga menjadi jelas, terang dan tidak multi tafsir dan diharapkan ketentuan tentang tanggung jawab Notaris setelah pensiun menjadi lebih tegas terkait batas maksimalnya agar tidak menimbulkan permasalahan antara para pihak maupun dengan Notaris sendiri dikemudian hari.

\section{DAFTAR PUSTAKA}

Adjie, H. (2008). Hukum Notaris Indonesia, (Tafsir Tematik terhadap UU No 30 Tahun 2004 tentang Jabatan 
Notaris). Surabaya: PT. Refika Aditama.

Amiruddin, \& Asikin, Z. (2012). Pengantar Metode Penelitian Hukum (6th ed.). Jakarta: Raja Grafindo Persada. Hendra, R. (2012). Tanggungjawab Notaris terhadap Akta Otentik yang Penghadapnya Mempergunakan Identitas Palsu di Kota Pekanbaru. Jurnal Ilmu Hukum, 3(1).

Muhammad, F. N., Widowaty, Y., \& Raharjo, T. (2019). Penerapan Sanksi Pidana Terhadap Pemalsuan Akta Otentik yang Dilakukan oleh Notaris. Media of Law and Sharia, 1(1), 1-13.

Notodisoerjo, R. S. (2010). Hukum Notariat di Indonesia Suatu Penjelasan. Jakarta: Rajawali Pers.

Prajitno, A. A. A. (2010). Pengetahuan Praktis tentang Apa dan Siapa Notaris di Indonesia? (1st ed.). Surabaya: Putra Media Nusantara.

Santyaningtyas, A. C., \& Zubaidi, R. (2020). Role of Land Deed Officials in Legal Satisfaction Guarantee for Complete Systematic Land Registration. Jurnal Notariil, 5(1), 49-57.

Tedjosaputro, L. (2020). Authentic Deed of Notary That Carries Criminal Charges. In International Conference on Law, Economics and Health (ICLEH 2020) Authentic (Vol. 140, pp. 508-510). Atlantis Press.

Tobing, G. H. L. (1996). Peraturan Jabatan Notaris (3rd ed.). Jakarta: Erlangga.

Tresna, R. (1993). Komentar HIR. Jakarta: Pradnya Paramita.

Utami, A. R., Ali, D., \& Din, M. (2016). Pertanggungjawaban Pidana Pejabat Notaris terhadap Tindak Pidana Pemalsuan Akta Autentik. Jurnal Ilmu Hukum, 4(2), 13-17. 